\title{
CHOLANGITIS BY CHRYSEOBACTERIUM MENINGOSEPTICUM
}

\author{
Arnaw Kishore ${ }^{1}$
}

\section{HOW TO CITE THIS ARTICLE:}

Arnaw Kishore. "Cholangitis by Chryseobacterium Meningosepticum". Journal of Evolution of Medical and Dental Sciences 2015; Vol. 4, Issue 67, August 20; Page: 11773-11775, DOI: 10.14260/jemds/2015/1697

ABSTRACT: Chryseobacterium meningosepticum, a gram negative bacterium predominantly found in soil and water is a nosocomial pathogen which is responsible for causing opportunistic infection and meningitis in children in hospital has become area of concern. We have described a case report of 64 year patient with Cholangitis who acquired the bacterium nosocomially.

KEYWORDS: Chryseobacterium meningosepticum, Gram Negative rod, Cholangitis, India.

INTRODUCTION: E. meningosepticum a gram negative bacillus formerly known as Flavobacterium reclassified as Chryseobacterium meningosepticum, was identified as a causative agent of meningitis in neonates and outbreaks have occasionally been described since 1961 was identified by Dr. Elizabeth King. ${ }^{1}$ The bacilli is non-motile, non-fermentative, catalase positive, oxidase positive and appears yellow pigmented, smooth and fairly large (1-2mm in diameter) on culture plates. Case reports have described patients with endocarditis, cellulitis, necrotizing fasciitis, hepatitis, osteomyelitis and eye infections and pneumonia. ${ }^{2}$ Outbreaks usually extend over a period of a few week $^{3,4}$ although they may last longer. ${ }^{5}$ Very few literatures are available infection caused by Chryseobacterium meningosepticum in Indian scenario. As far as search in Pubmed, Google scholar is concerned this is the first ever case report of Chryseobacterium meningosepticum in North India.

CASE REPORT: A 64 years old patient was admitted with complaints of yellowish discolouration of sclera and skin. The patient was having loss of appetite and itching all over the body. USG abdomen showed echogenic lesion filling the common duct and left hepatic duct with left lobe choliango carcinoma with metastasis grade IV bening prostrate hypertrophy. MRCP showed proximal CBD intraluminal lesion in left lobe. Patient had ERCP and stenting of both duct, subsequently he developed cholangitis sepsis with increasing trend of serum bilirubin $27.7 \mathrm{mg} / \mathrm{dl}$ and had to shift to ICU. Serum bilirubin started to decrease. The blood culture was send to the laboratory for culture and sensitivity. It was positive after 24 hours of incubation and was detected by Biomeriux BacT Alert 3D 60. The pathogen was sub cultured on Blood Agar, Chocolate Agar and MaC conkey Agar. There was no growth on $\mathrm{MaC}$ conkey Agar but small translucent convex non-hemolytic yellowish orange coloured pigmented colonies were produced on blood agar. The pathogen was identified as Chryseobacterium meningospeticum on the basis of biochemical reaction tested by API ID 32 G automated identification system (Biomeriux, Marcy I Etoile, France). These include the positive activity of oxidase, catalase, urease, indole. The organism was sensitive to Piperacillin, Piperacillintazobactum, Ceftazidime, Cefipime, Imipenem, Co-trimoxazole, Amikacin, Ciprofloxacin, Cefotaxime. Previous literatures also showed that the organism is sensitive to Imipenem, Cefemine, Piperacillintazobactum, Cotrimoxazole. The patient was given Amoxyclave, Meropenem, Aztreonam, Imipenem, and Cefepime but however the patient died. It is suggested that the patient has acquired the bacterium nosocomially. 
DISCUSSION: The organism is a biofilm forming, nosocomial pathogen is associated with invasive device such as vascular catheters and endotracheal tubes 6,7 and has been isolated from faucets, sinks, respiratory therapy equipment, feeding bottles, venous catheter lines, nutritional solutions, contaminated syringes in an ice chest, vials, feeding tubes, flush solutions in arterial catheters, pressure transducers, and antiseptic solutions. ${ }^{8,9}$ Immune suppression, comorbidities, use of broadspectrum antibiotics, and extreme age are other important risk factors for Chryseobacterium infections. ${ }^{10}$ The organism is predominantly found in soil and water six spp. of Chryseobacterium which is more commonly isolated from clinical specimen are C.meningosepticum, C.odoratum, C.multivorum, C.breve and grp II b Chryseobacterium spp which includes C. indolegenes and C.gleum. ${ }^{11}$ The genus represents only $0.27 \%$ of all processed Non fermentative gram negative bacilli and $0.03 \%$ of all bacterial isolates collected by SENTRY programme during 5 year period 1997-200.12 The highest frequency of Chryseobacterium spp. Infection has been reported from Taiwan includes 91 pneumonia and 22 bacteremia patients. ${ }^{13} \mathrm{C}$. meningosepticum produce extended spectrum betalactamases, and are resistant to penicillins, cephalosporins, and monobactams. In addition, they are long known to be highly resistant to aminoglycosides, tetracyclines, chloramphenicol, erythromycin, clindamycin, and teicoplanin are the Newer quinolones and rifampin are the most active antimicrobials. ${ }^{14,15}$ C.meningosepticum followed by C. indologenes and C.gleum were the most isolated Chryseobacterium spp. The literature on the antimicrobial activity of Chryseobacterium spp. is very limited. In addition, result of susceptibility test varies when different methods are used. The bacterium C.meningosepticum is emerging as an important nosocomial pathogen in recent years, being multi resistant pose a serious challenge to physicians. Positive identification enables prompt treatment and increases the chance of recovery. Hence a proper Infection control practices and measures along with proper microbiology identification and testing must be done.

\section{REFERENCES:}

1. Kim KK, Kim MK, Lim JH, Park HY, Lee ST. Transfer of Chryseobacterium meningosepticum and Chryseobacterium miricola to Elizabethkingia gen. Nov. as Elizabethkingia meningoseptica comb. Nov. and Elizabethkingia miricola comb. Nov. Int J Syst Evol Microbiol. 2005 May; 55 (Pt 3): 1287-93.

2. Hsu MS, Liao CH, Huang YT, Liu CY, Yang CJ, Kao KL, Hsueh PR. Clinical features, antimicrobial susceptibilities, and outcomes of Elizabethkingia meningoseptica (Chryseobacterium meningosepticum) bacteremia at a medical center in Taiwan, 1999-2006. Eur J Clin Microbiol Infect Dis. 2011 Oct; 30(10): 1271-8. doi: 10.1007/s10096-011-1223-0.

3. Abrahamsen TG, Finne PH, Lingaas E. Flavobacterium meningosepticum infections in a neonatal intensive care unit. Acta Paediatr Scand. 1989 Jan; 78(1): 51-5.

4. Bruun B, Jensen ET, Lundstrøm K, Andersen GE. Flavobacterium meningosepticum infection in a neonatal ward. Eur J Clin Microbiol Infect Dis. 1989 Jun; 8(6): 509-14.

5. Hazuka BT, Dajani AS, Talbot K, Keen BM. Two outbreaks of Flavobacterium meningosepticum type E in a neonatal intensive care unit. J Clin Microbiol. 1977 Nov; 6(5): 450-55.

6. Nulens E, Bussels B, Bols A, Gordts B, Van Landuyt HW. Recurrent bacteremia by Chryseobacterium indologenes in an oncology patient with a totally implanted intravascular device. Clin Microbiol Infect. 2001 Jul; 7(7): 391-3. 
7. Lin JT, Wang WS, Yen CC, Liu JH, Chiou TJ, Yang MH, Chao TC, Chen PM. Chryseobacterium indologenes bacteremia in a bone marrow transplant recipient with chronic graft-versus-host disease. Scand J Infect Dis. 2003; 35(11-12): 882-3.

8. Lin PY, Chu C, Su LH, Huang CT, Chang WY, Chiu CH. Clinical and microbiological analysis of bloodstream infections caused by Chryseobacterium meningosepticum in nonneonatal patients. J Clin Microbiol. 2004 Jul; 42(7): 3353-5.

9. Güngör S, Ozen M, Akinci A, Durmaz R. A Chryseobacterium meningosepticum outbreak in a neonatal ward. Infect Control Hosp Epidemiol. 2003 Aug; 24(8): 613-7.

10. Olbrich P, Rivero-Garvía M, Falcón-Neyra MD, Lepe JA, Cisneros JM,Marquez-Rivas J, Neth 0. Chryseobacterium indologenes central nervous system infection in infancy: an emergent pathogen? Infection. 2014 Feb; 42(1): 179-83.

11. Koneman EW, Allen SD, Janda WM, Schreckenberger PC, Winn WC. Colour atlas and textbook of diagnostic microbiology. $6^{\text {th }}$ ed Philadelphia: Lipincott; 2006.p. 345-52.

12. Di Pentima MC, Mason EO Jr, Kaplan SL. In vitro antibiotic synergy against Flavobacterium meningosepticum: implications for therapeutic options. Clin Infect Dis. 1998 May; 26(5): 116976. Review.

13. Chen FL, Wang GC, Teng SO, Ou TY, Yu FL, Lee WS. Clinical and epidemiological features of Chryseobacterium indologenes infections: analysis of 215 cases. J Microbiol Immunol Infect. 2013 Dec; 46(6): 425-32. doi: 10.1016/j.jmii.2012.08.007.

14. Kirby JT, Sader HS, Walsh TR, Jones RN. Antimicrobial susceptibility and epidemiology of a worldwide collection of Chryseobacterium spp: report from the SENTRY Antimicrobial Surveillance Program (1997-2001). J Clin Microbiol. 2004 Jan; 42(1): 445-8.

15. Hoque SN, Graham J, Kaufmann ME, Tabaqchali S. Chryseobacterium (Flavobacterium) meningosepticum outbreak associated with colonization of water taps in a neonatal intensive care unit. J Hosp Infect. 2001 Mar; 47(3): 188-92.

\section{AUTHORS:}

1. Arnaw Kishore

PARTICULARS OF CONTRIBUTORS:

1. Microbiologist, Department of Microbiology, Lab Services, Metro Heart Institute with Multispecialty.

FINANCIAL OR OTHER COMPETING INTERESTS: None
NAME ADDRESS EMAIL ID OF THE CORRESPONDING AUTHOR:

Arnaw Kishore, Maa Anandmayi Nagar,

Block Road, Ratu, Ranchi.

E-mail: kishore.arnaw@gmail.com

Date of Submission: 03/08/2015.

Date of Peer Review: 04/08/2015.

Date of Acceptance: 17/08/2015.

Date of Publishing: 20/08/2015. 